\title{
Validation of Emotional Stimuli Flashcards for Conducting 'Response to Reward' fMRI study among Malaysian students
}

Nisha Syed Nasser ${ }^{1,2}$,Hamed Sharifat ${ }^{1}$, Aida Abdul Rashid ${ }^{2}$, Suzana Ab Hamid ${ }^{2}$, Ezamin Abdul Rahim $^{2}$, Mazlyfarina Mohamad ${ }^{3}$, Rohit Tyagi ${ }^{4}$, Siti Irma Fadhilah Ismail ${ }^{5}$, Ching Siew Mooi ${ }^{6}$, Subapriya Suppiah ${ }^{1,2 *}$

${ }^{1}$ Centre for Diagnostic Nuclear Imaging, Faculty of Medicine and Health Sciences, Universiti Putra Malaysia, Malaysia

${ }^{2}$ Department of Imaging, Faculty of Medicine and Health Sciences, Universiti Putra Malaysia, Malaysia

${ }^{3}$ Department of Diagnostic Imaging and Radiotherapy Programme, Faculty of Health Sciences, Universiti Kebangsaan Malaysia, Malaysia

${ }^{4}$ Aerobe Pte. Ltd, Singapore

${ }^{5}$ Department of Psychiatry, Faculty of Medicine and Health Sciences, Universiti Putra Malaysia, 43400 Serdang, Selangor, Malaysia

${ }^{6}$ Department of Family Medicine, Faculty of Medicine and Health Sciences, Universiti Putra Malaysia, 43400 Serdang, Selangor, Malaysia 
medRxiv preprint doi: https://doi.org/10.1101/2020.01.17.20017202; this version posted April 21, 2020. The copyright holder for this preprint (which was not certified by peer review) is the author/funder, who has granted medRxiv a license to display the preprint in perpetuity.

\begin{abstract}
Problematic Instagram Use (PIGU) is a specific-Internet-addiction disorder observed among the youth of today. fMRI, is able to objectively assess regional brain activation in response to addiction-specific rewards, e.g. viewing picture flashcards. Pictures uploaded onto Instagram by PIGUs have often been associated with risky behaviours in their efforts to gain more 'Likes', thus it is hypothesized that PIGUs are more drawn to 'Negative-Emotional' cues. To date, there is no local database with addiction-specific cues. Objective: To conduct an out-of-scanner validation study to create a database of pictures using 'Negative-Emotional' cues that evoke responses of arousal among PIGUs. Method: Forty-four Malaysian undergraduate students (20 PIGUs, 24 controls) were randomly recruited based on the evaluation using the Smartphone-Addiction-ScaleMalay version (SAS-M) and modified Instagram Addiction Test (IGAT); and fulfilled Lin et al. (2016) definition of addiction. They were administered 200 content-specific pictures that were multidimensional i.e. arousal (excitation/relaxation effects), approach-avoidance (motivational direction) and emotional valence (positive/negative feelings) to describe the PIGUs perception of the psychological properties of the pictures using a 9-point Likert scale. Results: PIGUs viewing 'Negative-Emotional' cues demonstrated significant positive correlations between arousal \& valence $(z=4.834, p<.001$, effect size $=0.69)$ and arousal $\&$ avoidance-approach $(z=4.625, p$ $<.001$, effect $\operatorname{size}=0.66$ ) as compared to controls and were more frequently aroused by 'NegativeEmotional' type of stimuli. Conclusion: A database of validated, addiction-specific pictures can be developed to potentiate any future cue-induced response to reward fMRI studies to assess PIGU.
\end{abstract}

Keywords: Addiction, Affective ratings, Cravings, Picture database, Reward 
medRxiv preprint doi: https://doi.org/10.1101/2020.01.17.20017202; this version posted April 21, 2020. The copyright holder for this preprint (which was not certified by peer review) is the author/funder, who has granted medRxiv a license to display the preprint in perpetuity.

\section{Introduction}

Problematic Instagram Use (PIGU) is a behavioural addiction (BA) and considered as a type of specific-Internet-addiction, which is associated with cravings and overdependence of using Instagramsocial networking application (SNA) despite experiencing deterioration in activities of daily living among the addicted individual (Billieux 2012; Brand et al. 2016). To be precise, addiction is defined as a compulsive behaviour associated with continued indulgence in pleasureseeking activities with no desire to give up, despite the detrimental effects (Volkow et al. 2016). Addiction is classically recognized as substance use disorders (SUDs) such as addiction to cannabis, tobacco, alcohol, hallucinogens, sedatives, caffeine, opioids, hypnotics, and anxiolytics; but also encompasses abnormal behaviours such as pathological gambling, preoccupation with the Internet, online gaming, and social networking (American Psychiatric Association 2013).

Instagram use among Malaysians has increased exponentially in the past decade giving rise to problematic behaviours related to its use (Khalid et al. 2018). Most studies have relied on questionnaire-based assessment e.g. the Smartphone Addiction Scale-Malay version (SAS-M) and modified Instagram Addiction Test (IGAT) (Ching et al. 2015; Syed Nasser et al. 2019) to establish commonalities between PIGU and other BA and SUDs, albeit lacking in neurobiological evidence to support the hypothesis. Advantageously, functional magnetic resonance imaging (fMRI) neuroimaging technique can objectively assess regional brain activations in response to addictionspecific rewards. In addition to using the questionnaire-based scoring criteria, PIGU is defined by a set of modified diagnostic criteria for smartphone addiction, which is an objective assessment as proposed by Lin et al. (2016). 
medRxiv preprint doi: https://doi.org/10.1101/2020.01.17.20017202; this version posted April 21, 2020. The copyright holder for this preprint (which was not certified by peer review) is the author/funder, who has granted medRxiv a license to display the preprint in perpetuity.

All rights reserved. No reuse allowed without permission.

PIGU can be defined as a modification of the proposed diagnostic criteria for smartphone addiction by replacing the word "the Smartphone" with the word "Instagram" that gives the sensitivity, specificity and diagnostic accuracy of $79.4 \%, 87.5 \%$, and $84.3 \%$ respectively. The criteria comprise of three parts occurring within a 3-month period, namely (1) Criterion A: presence of $\geq$ 3 out of six symptoms (Repeated inability to resist using the Smartphone, Withdrawal symptoms as evidenced by dysphoric mood, irritability and anxiety when away from the smartphone for any period of time, Prolonged usage of the Smartphone for durations longer than initially intended, Unsuccessful attempts to reduce the Smartphone usage, Excessive preoccupations with using the Smartphone or preoccupied with the thoughts of quitting its use, Continued excessive use of the Smartphone despite knowledge of having a persistent or recurrent psychological or physical problem as a result of its overuse); (2) Criterion B: the presence of $\geq 2$ out of four functional impairment criteria assessed by replacing the words "Smartphone use" or SPU with "Instagram" (Excessive SPU resulting in recurrent psychological or physical problems, SPU in a physically dangerous, risky or hazardous situation (e.g., SPU while driving or crossing a road), or having other detrimental impacts on daily living, SPU causing impairment of school achievement, interpersonal relationships, or job performance, Excessive SPU leading to significant subjective distress, or is time-consuming and (3) exclusion criteria, whereby the BA is not better explained by an underlying psychiatric condition such as bipolar disorder or obsessive-compulsive disorder (Lin et al. 2016).

Additionally, by utilising fMRI, it is possible to illustrate in vivo brain activations in 'Response to Reward' conditions to better understand the neurobiology of this type of addiction (Sun et al. 2012; Kim et al. 2014; Zhang et al. 2016). Task-based fMRI employs Blood Oxygen Level Dependent 
medRxiv preprint doi: https://doi.org/10.1101/2020.01.17.20017202; this version posted April 21, 2020. The copyright holder for this preprint (which was not certified by peer review) is the author/funder, who has granted medRxiv a license to display the preprint in perpetuity.

All rights reserved. No reuse allowed without permission.

Imaging (BOLD) to measure the hemodynamic response function (HRF) i.e., outshoot of oxygenated blood to local brain areas that are activated during tasks such as viewing pictures, videos, and decision-making in the cerebral cortex (Glover 2011; Sharifat et al. 2018; Lindquist et al. 2009; Huettel et al. 2014). This is particularly pertinent as according to the 'Incentive sensitization theory of addiction', attention bias and pathological motivation toward addictionrelated cues such as pictures, movies, and words tended to elicit higher levels of arousal/ cravings in addicted individuals (Robinson and Berridge 2008).

Capra (1996), defined a paradigm as "a group of values, concepts, perceptions and practices that are shared by a community, which forms a unique vision of reality that is the foundation of the way a community organizes itself". Paradigms are used to investigate individual differences, group behaviour, organizational behaviour, human factors, and cognitive behaviour among a group of subjects. In specific, an experimental fMRI paradigm refers to a temporal allocation of stimuli to obtain good BOLD activations by employing sensory cues e.g. emotional visual stimuli that are embedded in a block or event-related design to evoke HRF in the subjects (James et al. 2014). Designing a proper fMRI paradigm enables the researcher to achieve a good response accuracy and subsequently, identify regional brain activations in response to the stimulus being presented.

Increased craving or euphoria in an addicted subject can be studied by cue-reactivity paradigms using emotional visual cues to elicit feelings of arousal and craving during reward anticipation or 'Response to Reward' during reward delivery among the pathological users; as compared to the control group. It is one of the widely employed paradigms to evoke and evaluate craving for pathological gambling, Internet addiction, smartphone addiction, and pathological Instagram and 
medRxiv preprint doi: https://doi.org/10.1101/2020.01.17.20017202; this version posted April 21, 2020. The copyright holder for this preprint (which was not certified by peer review) is the author/funder, who has granted medRxiv a license to display the preprint in perpetuity.

All rights reserved. No reuse allowed without permission.

Facebook usage (Chakraborty 2016; Sherman et al. 2018; Ko et al. 2009; Niu et al. 2016; Brand et al. 2016; Syed Nasser et al. 2019). A relatively new parameter with regards to the study of PIGU is the study of emotions. The exact nature of emotional motivational states in PIGU has not yet been adequately understood. Emotional stimuli are characterized by dimensions such as arousal, approach-avoidance (motivational direction) and emotional valence to describe the human perception of physical properties of the stimuli. Valence describes the feeling of pleasure in terms of positive or negative feelings evoked by the visual cues. Arousal is a physiological activity ranging from aroused/excited to unaroused/relaxed. Motivational direction refers to the directional aspect of the behaviour i.e., whether the respondent will decide to move towards/approach the stimuli or move away/avoid that stimuli (Feldman-Barrett et al. 2006; Mauss and Robinson 2009). Studies related to SNA have identified that the youth of today, namely young adults, tend to post 'selfies' on social media to gain peer approval and popularity via receiving 'Likes'(Sherman et al. 2018). The uploaded risky and emotional negative posts -which often contain pictures taken from dangerous heights, rooftops, towers, near railway lines and on the road and photos with problematic interpersonal relationships such as with ex-boyfriends or ex-girlfriends - to receive 'Likes' from their peers (Kurniawan et al. 2017) and vice versa the evidence of risky lifestyle behaviours such as taking illicit drugs, alcoholism, eating disorders, etc. among the youth of today can be sought through data mining of publicly available Instagram posts (Zhou et al. 2017). Thus, we hypothesize risky and negative emotional pictures act as rewarding visual cues that can effectually modulate emotional experiences among PIGU in this age group. Hence, appropriate emotional cues for neuroimaging studies can be selected based on the ratings of these dimensional categories. 
medRxiv preprint doi: https://doi.org/10.1101/2020.01.17.20017202; this version posted April 21, 2020. The copyright holder for this preprint (which was not certified by peer review) is the author/funder, who has granted medRxiv a license to display the preprint in perpetuity.

All rights reserved. No reuse allowed without permission.

Validated flashcard sets or image databases are invaluable for a good cue-induced reactivity fMRI study. Although the availability of standardized databases such as the International Affective Picture System, and the Geneva Affective Picture Database that contain emotionally charged stimuli cannot be denied, there is no particular database on Smartphone-linked Instagram addiction; thus lacking appropriate images for potential future cue-induced fMRI studies to evaluate the 'Response to Reward' condition among smartphone addicts particularly in the domain of social networking applications such as Instagram.

To date, there is no local database with addiction-specific cues on PIGU that can elicit robust brain activations and portray similar neurobiological mechanisms as shown in SUDs. The main objective of this study is to validate a set of flashcards that can induce 'Negative Emotional Valence' and can potentially elicit brain activations in PIGU subjects. We aimed to create a database of 'Neutral' cues as a baseline and 'Negative Emotional' cues as the rewarding cues for future fMRI studies on PIGU. This validation study was designed and modified based on the method used by the Nencki Affective Picture System (NAPS)(Marchewka et al. 2014).

\section{Materials and Methods}

We modified Sherman's method on the assessment of the power of 'Likes' to evaluate the 'Response to Reward' condition employing negative emotional stimuli and 'Neutral' cues (Sherman et al. 2016). The pictures for this current study were selected from publicly available Instagram accounts after receiving approval from the account holders. The pictures were collected and classified into two categories ('Negative Emotional' cues and 'Neutral' cues). The former category included photographs such as 'selfies' taken from heights, taking photos while driving, 
medRxiv preprint doi: https://doi.org/10.1101/2020.01.17.20017202; this version posted April 21, 2020. The copyright holder for this preprint (which was not certified by peer review) is the author/funder, who has granted medRxiv a license to display the preprint in perpetuity.

All rights reserved. No reuse allowed without permission.

loss of an interpersonal relationship and photos that were taken while doing dangerous and risky stunts. The latter category included pictures of landscapes, plants, trees, and object photographs in a greyscale background. Grayscale images provide very little information and elicit less interest compared to coloured images, hence it can reduce the involvement of the human visual system in extracting information from the images (Kather et al. 2017).

The initial classification of pictures into the selected categories was made by the principal team members (NSN, HS, AAR, SS). The selected images were then shown to 3 independent consultants (CSM, SIF, MFM), who gave their impartial opinion on the images by consensus. They acted as impartial judges to classify the pictures into 2 categories. Very bright, colourful pictures that provoked any positive emotions or a feeling of arousal were excluded under the 'Neutral' category. 'Negative Emotional' cues depicting photos taken in religious or sacred places were excluded to avoid any disputes. Any blurred photographs from both categories were excluded. At the beginning of the study, we had 300 pictures, out of which 100 'Neural" pictures and 100 'Negative Emotional' pictures were selected. In approximately $99 \%$ of the cases, all of the judges classified the pictures into the same category (Cronbach's $\alpha=.99)$. The finalized pictures $(n=200)$, were then processed for the specifications of an fMRI paradigm. The pictures were resized and cropped to the specification of $600 \times 400$ with a resolution of 300 dpi using the freely available software, 'Irfan View' (sourced from https://www.irfanview.com/). The pictures were using JEPG file format.

\section{Participants}

After acquiring ethical clearance from the local institutional committee (JKEUPM) (UPM/TNCPI/RMC/1.4.18.2), a validation study was conducted among 44 undergraduate 
medRxiv preprint doi: https://doi.org/10.1101/2020.01.17.20017202; this version posted April 21, 2020. The copyright holder for this preprint (which was not certified by peer review) is the author/funder, who has granted medRxiv a license to display the preprint in perpetuity.

All rights reserved. No reuse allowed without permission.

students, 20 PIGU (16 girls, 4 boys; mean age 22.05 years) and 24 control subjects (18 girls, 6 boys; mean age 21.75 years) from Universiti Putra Malaysia. The subjects were recruited based on the evaluation of the online SAS-M and the modified IGAT questionnaires. Based on the recommended cut-off scores, subjects who attained a total score of $\geq 98$ on SAS-M and $\geq 37$ on the modified IGAT, along with the fulfillment of the diagnostic criteria proposed by Lin et al. (2016); were considered as PIGU. Conversely, those with a lower score from the cutoff values and who did not fulfill the diagnostic criteria were categorized as controls. Recruitment of participants for the study was made by advertising in the student portals and via communication with lecturers across all the faculties in Universiti Putra Malaysia (UPM). Responding participants were undergraduate students from various faculties in UPM and were selected by simple random sampling. Informed consent was obtained from all individual participants and the study abided by the rules advocated by the Declaration of Helsinki 1964.

\section{Rating scales and stimuli presentation}

Before the commencement of the study, a briefing session was conducted among the study participants. The participants were instructed to answer the questions honestly and without discussing it with other people. The stimuli from both the categories were presented alternatively; with the limitation that no more than three stimuli from each category were presented in consecutive succession. The participants were instructed to view each picture for $3 \mathrm{~s}$ and then respond to the 3 sub-questions related to emotional valence, motivation and arousal, for a duration of 3s each (see Appendix: Supplementary file 1).

We used an online picture evaluation method to rate our flashcards on a 9 point rating scale. The 
participant had to complete the sentence on the valence scale as "You are judging this image as ..." (from $1=$ very negative to $9=$ very positive, with $5=$ 'Neutral'). Secondly, the participants judged the motivational direction by completing the sentence, "My reaction to this image is ..." (from $1=$ to avoid to $9=$ to approach, with $5=$ 'Neutral'). Finally, participants judged the degree of arousal elicited by the pictures with the introductory sentence, "Confronted with this image, you are feeling: ..." (From $1=$ relaxed to $9=$ aroused, with $5=$ 'Neutral'/ambivalent). The duration of the study was 45 minutes. The validation form was emailed to the participants and the responses were obtained via an online link. All responses were further analyzed using the statistical package SPSS version 22 .

\section{Results}

The ratings and descriptive statistics for the dimensions and pictures in each category by groups are presented in Table 1. PIGU and control groups showed differing emotional responses to the 'Negative Emotional' cues. Within the PIGU group, the 'Negative Emotional' cues elicited a positive feeling and they got aroused and preferred to approach those pictures. Whereas, the control group, although aroused by the 'Negative Emotional' cues, preferred to respond by avoiding those pictures. Both groups rated the 'Neutral' cues as pleasant and relaxing/un-arousing and were apt to approach those pictures. 
medRxiv preprint doi: https://doi.org/10.1101/2020.01.17.20017202; this version posted April 21, 2020. The copyright holder for this preprint (which was not certified by peer review) is the author/funder, who has granted medRxiv a license to display the preprint in perpetuity. All rights reserved. No reuse allowed without permission.

Table 1. Descriptive statistics calculated separately for each dimension and category in the target groups

\begin{tabular}{|c|c|c|c|c|c|c|c|}
\hline \multirow[t]{2}{*}{ Category } & & \multicolumn{2}{|c|}{ PIGU group } & \multicolumn{4}{|c|}{ Control group } \\
\hline & & $\mathbf{A}$ & B & $\mathrm{C}$ & $\mathbf{A}$ & B & $\mathbf{C}$ \\
\hline 'Negative & Mean \pm & $5.005 \pm$ & $4.83 \pm$ & $5.60 \pm$ & $4.445 \pm$ & $4.304 \pm$ & $5.697 \pm$ \\
\hline \multirow[t]{3}{*}{ Emotional' } & SD & 0.945 & 0.941 & 0.480 & 1.020 & 1.020 & 0.643 \\
\hline & Min-Max & $2.60-7.1$ & $2.45-7.1$ & $3.9-6.8$ & $2.67-7.21$ & $2.5-7.08$ & $3.83-7.13$ \\
\hline & $\mathbf{N}$ & 100 & 100 & 100 & 100 & 100 & 100 \\
\hline \multirow[t]{5}{*}{ 'Neutral' } & Mean \pm & $6.165 \pm$ & $6.011 \pm$ & $4.765 \pm$ & $6.292 \pm$ & $6.294 \pm$ & $4.043 \pm$ \\
\hline & SD & 0.613 & 0.607 & 0.452 & 0.639 & 0.684 & 0.636 \\
\hline & Min- & $3.7-7.5$ & $3.5-7.35$ & $3.65-5.7$ & $4.08-7.63$ & $3.96-7.58$ & $2.83-5.71$ \\
\hline & $\operatorname{Max}$ & & & & & & \\
\hline & $\mathbf{N}$ & 100 & 100 & 100 & 100 & 100 & 100 \\
\hline 'Negative & Mean \pm & $5.585 \pm$ & $5.420 \pm$ & $5.187 \pm$ & $5.369 \pm$ & $5.299 \pm$ & $4.87 \pm$ \\
\hline Emotional' & SD & 0.986 & 0.987 & 0.629 & 1.256 & 1.322 & 1.046 \\
\hline \multirow[t]{2}{*}{ and 'Neutral' } & Min- & $2.60-7.5$ & $2.45-7.35$ & $3.65-6.8$ & $2.67-7.63$ & $2.5-7.58$ & $2.83-7.13$ \\
\hline & Max & & & & & & \\
\hline combined & $\mathbf{N}$ & 200 & 200 & 200 & 200 & 200 & 200 \\
\hline
\end{tabular}


medRxiv preprint doi: https://doi.org/10.1101/2020.01.17.20017202; this version posted April 21, 2020. The copyright holder for this preprint (which was not certified by peer review) is the author/funder, who has granted medRxiv a license to display the preprint in perpetuity.

All rights reserved. No reuse allowed without permission.

\section{Correlation analyses of emotional dimensions for the groups and categories}

Taking the pictures as cases, we conducted a correlation analyzing using Pearson's correlations to examine the relationships between ratings of valence, arousal, and approach-avoidance for each category and group separately; as described in Table 2 and shown in Figure 1, 2 and 3 respectively. All dimensions were highly correlated in both the PIGU group and the control group $(\mathrm{p}<0.001)$ as demonstrated in Table 2. The control group, however, had a strong negative correlation compared to the PIGU group in all cases, except for the correlations between approach-avoidance and arousal, in which both groups exhibited a strong positive correlation. Correlation coefficients of the control group were also directly compared to those of the addicted group using a calculation for the test of the difference between two independent correlation coefficients (Preacher, 2002). This calculation involves converting the two correlation coefficients into z scores using Fisher's rto-z transformation. Then, making use of the sample size employed to obtain each coefficient, these z scores are compared using Formula 2.8.5 from Cohen and Cohen (1983, p.54):

$$
\mathbf{Z}=\mathbf{Z 1}-\mathbf{Z 2} / \mathbf{S D Z}
$$

Where, $\mathrm{SDZ}=\sqrt{[1 /(\mathrm{N} 1-3)+1 /(\mathrm{N} 2-3)]}$, and $\mathrm{N} 1$ and $\mathrm{N} 2$ are the sample sizes.

In case of the correlation between emotional valence and arousal, the differences between the PIGU group and control group for the 'Negative Emotional' category showed a strong positive effect $(z=4.834, p<.001$, effect size $=0.69)$ compared to (control group-PIGU group), which showed a strong negative effect $(\mathrm{z}=-4.83)$. Similarly, in the case of arousal correlated with approach-avoidance, the differences between the PIGU group and control group (PIGU groupcontrol group) for the 'Negative Emotional' category, showed a strong positive correlation ( $\mathrm{z}=$ 4.625, $\mathrm{p}<0.001$, effect size $=0.66$ ) compared to (control group- PIGU group), which showed a 
medRxiv preprint doi: https://doi.org/10.1101/2020.01.17.20017202; this version posted April 21, 2020. The copyright holder for this preprint (which was not certified by peer review) is the author/funder, who has granted medRxiv a license to display the preprint in perpetuity.

All rights reserved. No reuse allowed without permission.

strong negative correlation $(\mathrm{z}=-4.625)$. For the condition of emotional valence correlated with approach-avoidance differences between the (control group- PIGU group) for the 'Negative Emotional' category showed a medium positive correlation $(\mathrm{z}=2.32, \mathrm{p}<0.001$, effect size $=0.33)$ compared to (PIGU group-control group), which showed a medium negative correlation ( $\mathrm{z}=-2.32)$.

Table 2. Pearson's correlation of ratings of valence, arousal and approach-avoidance for each category in the target groups

\begin{tabular}{|c|c|c|c|c|c|}
\hline & & $\begin{array}{l}\text { PIGU group } \\
\text { Pearson's 'r' }\end{array}$ & & $\begin{array}{l}\text { Control group } \\
\text { Pearson's 'r' }\end{array}$ & \\
\hline Category & Dimension & $\mathbf{C}$ & $\mathbf{A}$ & $\mathbf{C}$ & $\mathbf{A}$ \\
\hline \multirow{3}{*}{$\begin{array}{c}\text { 'Negative } \\
\text { Emotional' }\end{array}$} & $\mathbf{A}$ & $-.372 *$ & & $-.795^{*}$ & \\
\hline & & & & & \\
\hline & B & $-.423 *$ & $.971^{*}$ & $-.806^{*}$ & $.985^{*}$ \\
\hline \multirow[t]{2}{*}{ 'Neutral' } & $\mathbf{A}$ & $-.716^{*}$ & & $-.895^{*}$ & \\
\hline & B & $-.745^{*}$ & $.944 *$ & $-.905^{*}$ & $.980 *$ \\
\hline
\end{tabular}

A: Valence; B: Approach-Avoidance; C: Arousal

*Correlation is significant at $\mathrm{p}<0.05$ 


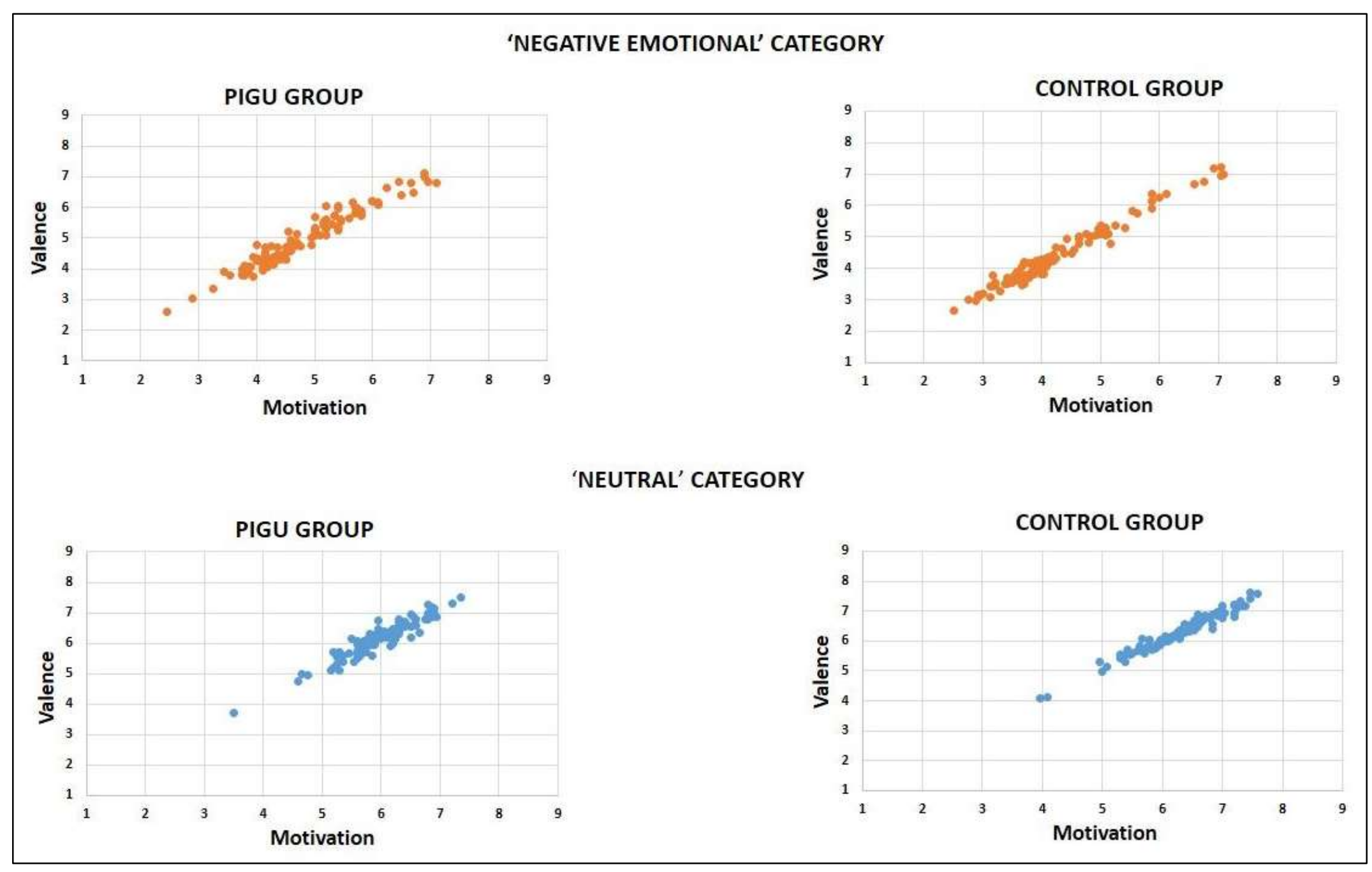

Figure 1. Scatter plot chart depicting the relationship between scores by PIGU and control groups for the two different image categories showing behavioral ratings for emotional valence (y-axis) and motivation ( $x$-axis) in each category for the PIGU and control groups.

* Every single dot represents the mean rating for a particular picture on a two-dimensional scale. 


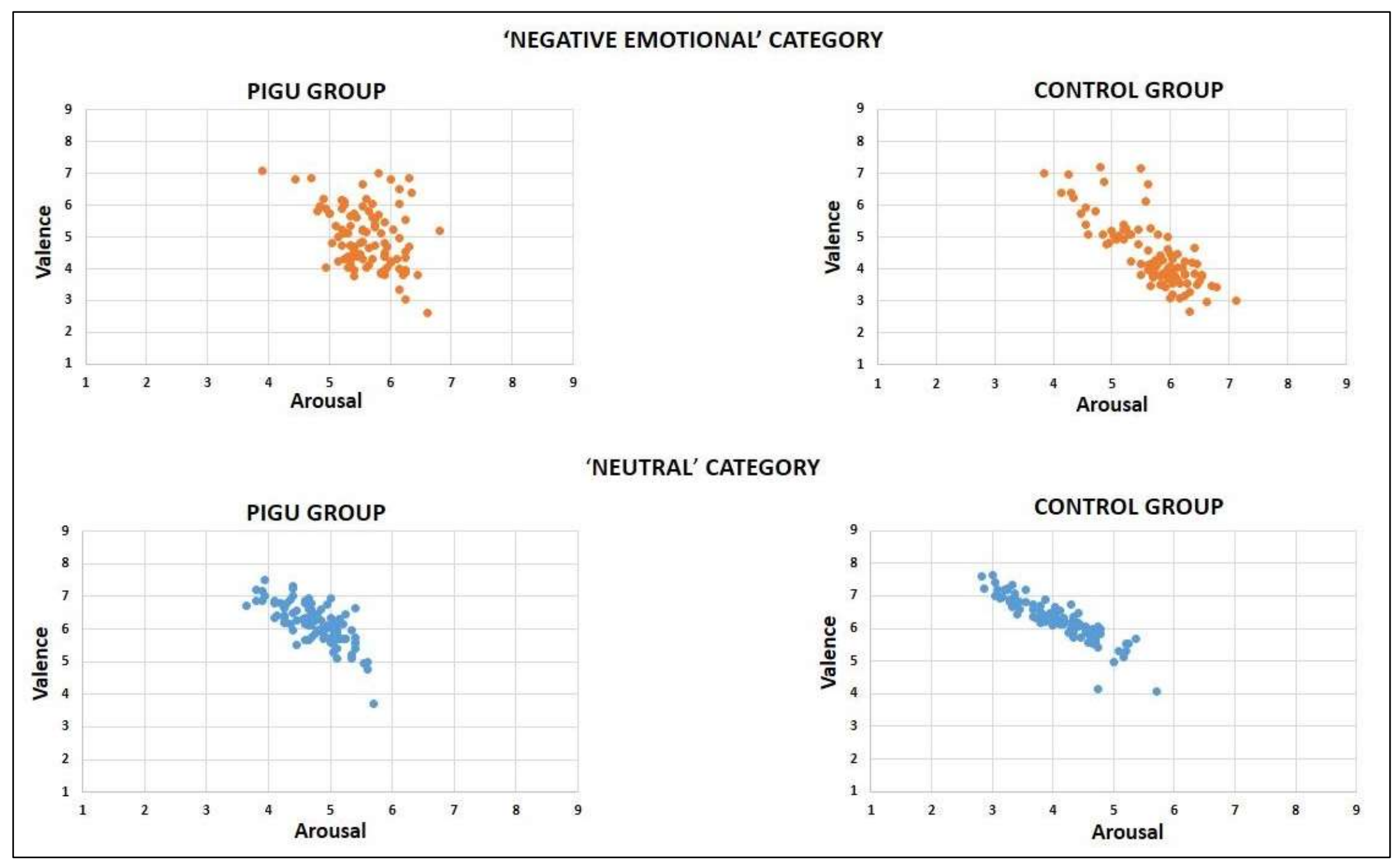

Figure 2. Scatter plot chart depicting the relationship between scores by PIGU and control groups for the two different image categories showing behavioral ratings for emotional valence ( $y$-axis) and arousal ( $x$-axis) in each category for the PIGU and control groups.

* Every single dot represents the mean rating for a particular picture on a two-dimensional scale. 


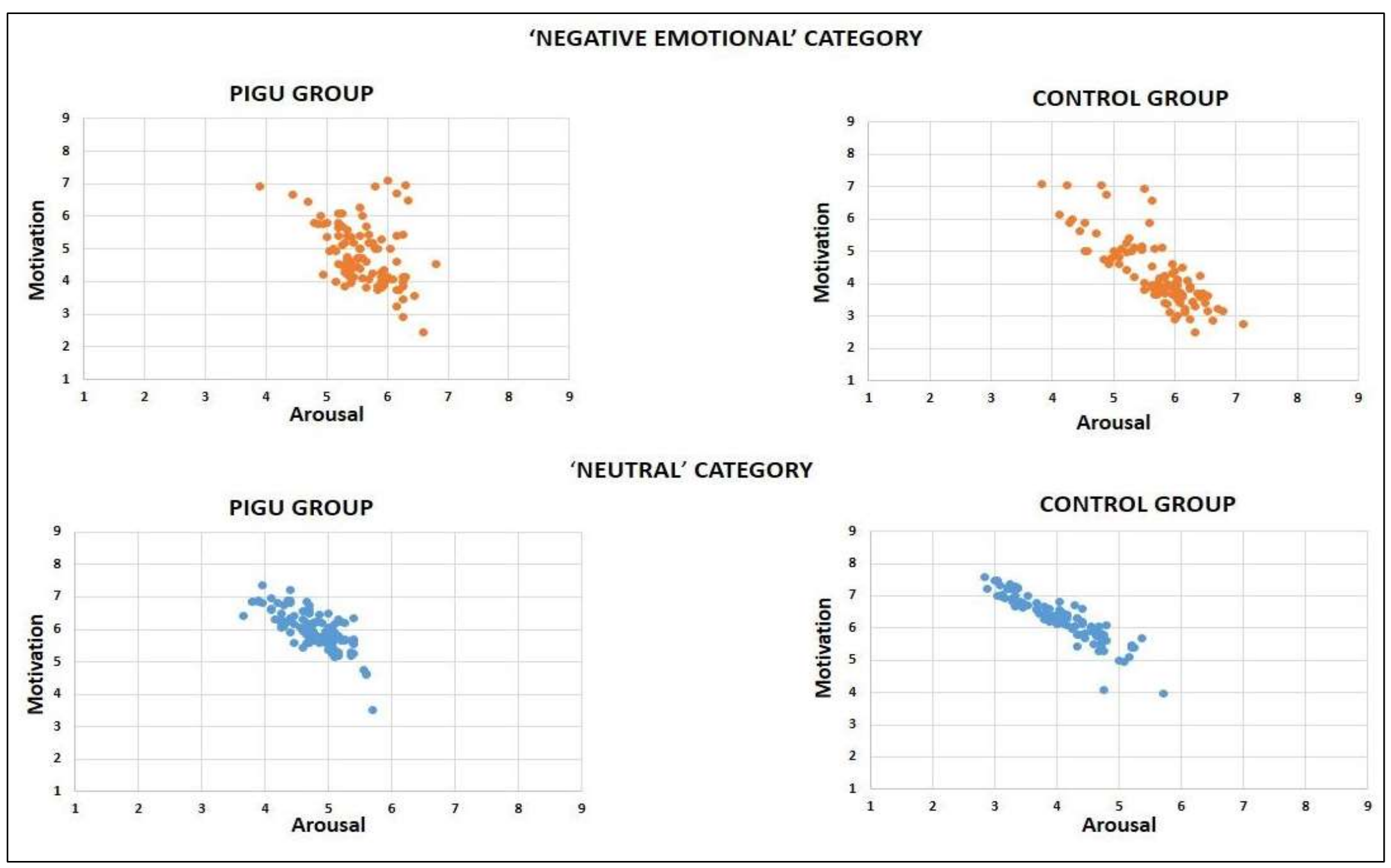

Figure 3. Scatter plot chart depicting the relationship between scores by PIGU and control groups for the two different image categories showing behavioral ratings for motivation ( $y$-axis) and arousal ( $x$-axis) in each category for the PIGU and control groups.

* Every single dot represents the mean rating for a particular picture on a two-dimensional scale. 
medRxiv preprint doi: https://doi.org/10.1101/2020.01.17.20017202; this version posted April 21, 2020. The copyright holder for this preprint (which was not certified by peer review) is the author/funder, who has granted medRxiv a license to display the preprint in perpetuity.

\section{Discussion}

This study focused on developing and validating visual cues called the 'Problematic Instagram Use Flashcards', with the focus on 'Negative Emotional Valence' cues to evoke an emotional response to risk-taking behaviour among the problematic Instagram users in the young adults' age group. Conversely, the 'Neutral' cues acted as a baseline stimulus to be used as addiction-specific cues in potential future fMRI studies.

In the process of creating this database, we focused on dividing the cues into 2 categories 'Negative Emotional' and 'Neutral' cues. The 'Negative Emotional' cues included images denoting problematic use of Instagram; such as pictures taken from high altitude, texting while driving, dangerous stunts and loss of an interpersonal relationship, which the PIGUs could perhaps relate to and deem as arousing to them. 'Neutral' cues involving nature and objects in grayscale and dullcoloured background were used as baseline stimuli. All the pictures in the present database were of good quality with a resolution of $300 \mathrm{dpi}$. We determined the correlations between emotional valence, arousal, and approach-avoidance for the 'Negative Emotional' and 'Neutral' categories, as scored by the PIGU and control groups.

The results suggest that there is a distinct profile for PIGU group with regards to their experience of emotions when presented with 'Negative Emotional' cues that we deem as addiction-specific cues. Taking into account the differences in the correlation coefficients between the 2 groups, together with the scatter plot charts, correlations between arousal and emotional valence, arousal and avoidance-approach were strongly positive in the PIGU group as compared to the control group for the 'Negative Emotional' category cues. We found that PIGU subjects compared to the 
medRxiv preprint doi: https://doi.org/10.1101/2020.01.17.20017202; this version posted April 21, 2020. The copyright holder for this preprint (which was not certified by peer review) is the author/funder, who has granted medRxiv a license to display the preprint in perpetuity.

All rights reserved. No reuse allowed without permission.

controls were vulnerable to addiction-specific cues and were more frequently aroused by 'Negative Emotional' type of stimuli as they frequently used such type of images to receive more 'Likes' on Instagram. When comparing between emotional valence and motivation among the controls, the pictures in the 'Negative Emotional' category were rated as unpleasant. Hence, they had perceived it as 'negative' and would prefer to 'avoid' these cues. In contrast to this, the PIGU subjects had abnormal perception and rated these stimuli to be pleasant. We postulate this to be a result of the abnormally accentuated need to gain popularity and acceptance among their peers that has forced the PIGU subjects to strongly indulge in risk-taking behaviours and had increased their motivation to seek risky situations. These findings are in line with the study by Volkow et al. (2010) that observed a greater activation of the motivation circuit upon exposure to drug cues, ultimately resulting in the compulsive intake of illicit drugs. In the latter study, addicted participants showed a tendency towards approaching the 'Negative Emotional' cues.

Next, when studying arousal compared with emotional valence, we found that 'Neutral' category cues did not elicit any excitement or arousal in both the PIGU and the control groups. Interestingly, when presented with 'Negative Emotional' cues, both groups reported increased ratings for arousal. This finding is consistent with the studies on Internet addiction and alcohol addiction, which reported non-addicts can also get aroused in response to the addictive cues (Sinha and $\mathrm{Li}$ 2007; Niu et al. 2016). This may be due to the daily use of the social networking application or closely associating this kind of behaviour with themselves, friends or family members (Niu et al. 2016).

Although both groups were aroused during the 'Negative Emotional' cues, we observed that the 
medRxiv preprint doi: https://doi.org/10.1101/2020.01.17.20017202; this version posted April 21, 2020. The copyright holder for this preprint (which was not certified by peer review) is the author/funder, who has granted medRxiv a license to display the preprint in perpetuity.

All rights reserved. No reuse allowed without permission.

mean rating of arousal in the control group was greater than that of the PIGU subjects. This is because the controls are not frequently exposed to risk-taking behaviours. Thus, when confronted with 'Negative Emotional' cues, which are considered "taboo", socially unaccepted and should be discouraged, they found it exciting (Duncan and Petosa 1994). Nevertheless, they correctly responded by avoiding such cues. As anticipated, the PIGU subjects were also aroused by these images and tended to respond by approaching these cues. Nevertheless, a few participants showed reduced arousal, which we speculate may be due to their over-involvement in extreme levels of risk-taking behaviour leading to the development of tolerance. Because of their chronic exposure to such content in their Instagram account, the PIGU group are postulated to become very aroused to extremely 'Negative Emotional' kind of images and will approach the 'Negative Emotional' cues.

Lastly, the age difference has a significant role in the processing of emotional stimuli. Age can also influence the degree of arousal and hence can affect brain activation in fMRI studies. Previous studies have found that older people, middle-aged people and younger adults differ in perception and processing of emotional stimuli. A study by Grühn and Scheibe (2008) found older people compared to the young adults over-rate emotional valence and arousal dimensions (Grühn and Scheibe 2008). Whereas, Gilet et al (2012) reported middle-aged people showed intense mean ratings for positive pictures compared to older people (Gilet et al. 2012). Thus, to avoid any bias and disputes, we limited the study to undergraduate students of a similar age group in a public university in Malaysia.

These results suggest that PIGU can produce long term alterations in the way the users experience emotions when presented with 'Negative Emotional' category cues. The decision-making towards 
medRxiv preprint doi: https://doi.org/10.1101/2020.01.17.20017202; this version posted April 21, 2020. The copyright holder for this preprint (which was not certified by peer review) is the author/funder, who has granted medRxiv a license to display the preprint in perpetuity.

All rights reserved. No reuse allowed without permission.

'Negative Emotional' cues was "stronger" among the control group to guide them towards adaptive objectives, rather than towards 'Negative Emotional' cues as observed among the PIGU subjects. Furthermore, neuroimaging studies have highlighted the role of emotional markers in decisionmaking (Bechara 2004; Bechara et al. 2002). The prefrontal cortex (PFC) is a key brain area responsible for decision-making to find solutions in a given task and decides whether to 'go' towards or to 'inhibit' the stimulus. In agreement with these studies, the decision-making in the PIGU group was affected when presented with 'Negative Emotional' cues due to inability to exhibit an inhibitory response to such stimuli (Syed Nasser et al. 2020). This study helps to explain why the 'Negative Emotional' cues associated with Instagram usage increases the motivational behaviour of the PIGU group towards such stimuli as opposed to the control group. This inability to regulate one's control of negative behaviour may lead to a distorted perception of social norms.

From a set of 100 pictures in each category, we finally selected 20 'Negative Emotional' and 20 'Neutral' pictures. The suitable 'Negative Emotional' pictures were selected on the basis that the pictures elicited a positive feeling and arousal and a tendency to approach among the PIGU subjects, while the same pictures rated as negative and induced a tendency to avoid among the control group. The pleasant, un-arousing pictures in both groups were selected as suitable 'Neutral' stimuli. The appropriate cues selected based on this validation study will enable the researchers to identify the regional brain activation in the mesocorticolimbic system in future fMRI studies.

This study focused specifically on the risk-taking behaviours of undergraduate students who are in the young adults' age group, hence it is likely that the behavioural influence may vary among adolescents as reported by Sherman et al. (2018) and older adults, who may be preoccupied with 
medRxiv preprint doi: https://doi.org/10.1101/2020.01.17.20017202; this version posted April 21, 2020. The copyright holder for this preprint (which was not certified by peer review) is the author/funder, who has granted medRxiv a license to display the preprint in perpetuity.

All rights reserved. No reuse allowed without permission.

different types of social norms and lifestyle behaviours. We recommend that future studies should design their paradigms to facilitate adolescents and adults who may require a different set of flashcards for an fMRI study that is targeted to age-specific content. Another limitation of this study is the small sample size and limited theme of flashcards stimuli. Further validation of this picture database employing computerized SAM or the slider scale methodology is recommended. Additionally, as we had conducted an online survey, we are unsure regarding the exact duration of time the subjects took to answer each question. An additional minor limitation of this present study is the lack of very negative (low emotional valence) pictures with a high avoidance-approach outcome.

\section{Conclusion}

A validated database of flashcard images on problematic Instagram usage has been created to potentiate future fMRI 'Response to Reward' cue-induced reactivity studies among young Malaysian adults. The database offers high-resolution addiction-specific cues that could potentially activate the mesocorticolimbic reward system of the brain when performing fMRI. Images from our database will be made available to interested researchers upon request made to the corresponding author.

\section{Acknowledgements}

This study was funded by Universiti Putra Malaysia research grants, Geran Putra (GPIPS/2017/9580800 and GP/2017/9549800) awarded to Associated Professor Dr. SubapriyaSuppiah. All the authors declare that there is no conflict of interest in the publication of this research. The authors would like to thank the students from different faculties of UPM who 
participated in this study.

\section{References}

American Psychiatric Association. 2013. Diagnostic and Statistical Manual of Mental Disorders. 5 ed.

Bechara, A. 2004. "The role of emotion in decision-making: Evidence from neurological patients with orbitofrontal damage." Brain and Cognition 55(1): 30-40.

Bechara, A., Dolan, S., and Hindes, A. 2002. "Decision-making and addiction (part II): myopia for the future or hypersensitivity to reward?" Neuropsychologia 40(10): 1690-1705.

Billieux, J. 2012. "Problematic use of the mobile phone: A literature review and a pathways model." Current Psychiatry Reviews 8(4): 299-307.

Brand, M., Young, K.S., Laier, C., Wölfling, K., and Potenza, M.N. 2016. "Integrating psychological and neurobiological considerations regarding the development and maintenance of specific Internet-use disorders: An Interaction of Person-Affect-CognitionExecution (I-PACE) model." Neuroscience \& Biobehavioral Reviews 71: 252-266.

Capra, F. 1996. The web of life: A new scientific understanding of living systems. New York: Anchor Books.

Chakraborty, A. 2016. "Facebook Addiction: An Emerging Problem." American Journal of Psychiatry Residents' Journal 11(12): 7-9.

Ching, S.M., Yee, A., Ramachandran, V., Sazlly Lim, S.M., Wan Sulaiman, W.A., Foo, Y.L., and Hoo, F.k. 2015. "Validation of a Malay Version of the Smartphone Addiction Scale among Medical Students in Malaysia." PLOS ONE 10(10): e0139337.

Duncan, D., and Petosa, R. 1994. "Social and Community Factors Associated with Drug Use and Abuse Among Adolescents." In: Gullotta, T., Adams, G., Montemayor, R. (eds.), Substance 
medRxiv preprint doi: https://doi.org/10.1101/2020.01.17.20017202; this version posted April 21, 2020. The copyright holder for this preprint (which was not certified by peer review) is the author/funder, who has granted medRxiv a license to display the preprint in perpetuity.

Abuse in Adolescents. Thousand Oaks, CA: Sage, 56-91

Feldman-Barrett, L., Mesquita, B., Ochsner, K.N., and Gross, J.J. 2006. "The Experience of Emotion." Annual Review of Psychology 58(1): 373-403.

Gilet, A.L., Grühn, D., Studer, J., and Labouvie-Vief, G. 2012. "Valence, arousal, and imagery ratings for 835 French attributes by young, middle-aged, and older adults: The French Emotional Evaluation List (FEEL)." Revue Européenne de Psychologie Appliquée/European Review of Applied Psychology 62(3): 173-181.

Glover, G.H. 2011. "Overview of functional magnetic resonance imaging." Neurosurgery clinics of North America 22(2): 133-vii.

Grühn, D., and Scheibe, S. 2008. Age-related differences in valence and arousal ratings of pictures from the International Affective Picture System (IAPS): Do ratings become more extreme with age? Vol. 40 .

Huettel, S.A., Song, A.W., and McCarthy, G. 2014. Functional Magnetic Resonance Imaging. 3 ed.: Sinauer Assosiates.

James, J.S., Rajesh, P., Chandran, A.V., and Kesavadas, C. 2014. "fMRI paradigm designing and post-processing tools." The Indian journal of radiology \& imaging 24(1): 13-21.

Kather, J.N., Weidner, A., Attenberger, U., Bukschat, Y., Weis, C.-A., Weis, M., Schad, L.R., and Zöllner, F.G. 2017. "Color-coded visualization of magnetic resonance imaging multiparametric maps." Scientific Reports 7: 41107.

Khalid, N.L., Jayasainan, S.Y., and Hassim, N. 2018. "Social media influencers - shaping consumption culture among Malaysian youth." SHS Web Conf. 53: 02008.

Kim, J.E., Son, J.W., Choi, W.H., Kim, Y.R., Oh, J.H., Lee, S., and Kim, J.K. 2014. "Neural responses to various rewards and feedback in the brains of adolescent Internet addicts 
medRxiv preprint doi: https://doi.org/10.1101/2020.01.17.20017202; this version posted April 21, 2020. The copyright holder for this preprint (which was not certified by peer review) is the author/funder, who has granted medRxiv a license to display the preprint in perpetuity. All rights reserved. No reuse allowed without permission.

detected by functional magnetic resonance imaging." Psychiatry Clin Neurosci 68(6): 46370.

Ko, C.H., Liu, G.C., Hsiao, S., Yen, J.Y., Yang, M.J., Lin, W.C., Yen, C.F., and Chen, C.S. 2009. "Brain activities associated with gaming urge of online gaming addiction." Journal of Psychiatric Research 43(7): 739-747.

Kurniawan, Y., Habsari, S.K., and Nurhaeni, I.D.A. 2017. "Selfie culture: Investigating the patterns and various expressions of dangerous selfies and the possibility of government's intervention." The 2nd Journal of Government and Politics International Conference: 324332.

Lin, Y.-H., Chiang, C.-L., Lin, P.-H., Chang, L.-R., Ko, C.-H., Lee, Y.-H., and Lin, S.-H. 2016. "Proposed Diagnostic Criteria for Smartphone Addiction." PLOS ONE 11(11): e0163010.

Lindquist, M.A., Meng Loh, J., Atlas, L.Y., and Wager, T.D. 2009. "Modeling the hemodynamic response function in fMRI: efficiency, bias and mis-modeling." NeuroImage 45(1 Suppl): S187-S198.

Marchewka, A., Zurawski, L., Jednorog, K., and Grabowska, A. 2014. "The Nencki Affective Picture System (NAPS): introduction to a novel, standardized, wide-range, high-quality, realistic picture database." Behav Res Methods 46(2): 596-610.

Mauss, I.B., and Robinson, M.D. 2009. "Measures of emotion: A review." Cognition \& emotion 23(2): 209-237.

Niu, G.-F., Sun, X.-J., Subrahmanyam, K., Kong, F.-C., Tian, Y., and Zhou, Z.-K. 2016. "Cueinduced craving for Internet among Internet addicts." Addictive Behaviors 62: 1-5.

Robinson, T.E., and Berridge, K.C. 2008. "Review. The incentive sensitization theory of addiction: some current issues." Philosophical transactions of the Royal Society of London. Series B, 
medRxiv preprint doi: https://doi.org/10.1101/2020.01.17.20017202; this version posted April 21, 2020. The copyright holder for this preprint (which was not certified by peer review) is the author/funder, who has granted medRxiv a license to display the preprint in perpetuity. All rights reserved. No reuse allowed without permission.

Biological sciences 363(1507): 3137-3146.

Sharifat, H., Rashid, A.A., and Suppiah, S. 2018. "Systematic review of the utility of functional MRI to investigate internet addiction disorder: Recent updates on resting state and taskbased fMRI." Malaysian Journal of Medicine and Health Sciences 14(1): 21-33.

Sherman, L.E., Greenfield, P.M., Hernandez, L.M., and Dapretto, M. 2018. "Peer Influence Via Instagram: Effects on Brain and Behavior in Adolescence and Young Adulthood." Child Dev 89(1): 37-47.

Sherman, L.E., Payton, A.A., Hernandez, L.M., Greenfield, P.M., and Dapretto, M. 2016. "The Power of the Like in Adolescence: Effects of Peer Influence on Neural and Behavioral Responses to Social Media." Psychological Science 27(7): 1027-1035.

Sinha, R., and Li, C.S.R. 2007. "Imaging stress- and cue-induced drug and alcohol craving: association with relapse and clinical implications." Drug and Alcohol Review 26(1): 25-31.

Sun, Y., Ying, H., Seetohul, R.M., Xuemei, W., Ya, Z., Qian, L., Guoqing, X., and Ye, S. 2012. "Brain fMRI study of crave induced by cue pictures in online game addicts (male adolescents)." Behav Brain Res 233(2): 563-76.

Syed Nasser, N., Ahmad Saad, F.F., Abdul Rashid, A., Mustafa, S., Sharifat, H., Tyagi, R., Abd Rashid, A.F., Loh, J.L., Mohamad, M., and Suppiah, S. 2020. "The objective assessment of the effects on cognition functioning among military personnel exposed to hypobarichypoxia: A pilot fMRI study." Med J Malaysia 75(1): 62-67.

Syed Nasser, N., Loh, J.L., Abdul Rashid, A., Sharifat, H., Ab Hamid, S., Abdul Rahim, E., Ng Andrew, B., Mustafa, S., Ching, S.M., and Suppiah, S. 2019. "Assessment of problematic Facebook use among undergraduate students in UPM correlated with depression, anxiety and stress " International Journal of Public Health and Clinical Sciences 6(4): 113-132. 
medRxiv preprint doi: https://doi.org/10.1101/2020.01.17.20017202; this version posted April 21, 2020. The copyright holder for this preprint

(which was not certified by peer review) is the author/funder, who has granted medRxiv a license to display the preprint in perpetuity.

All rights reserved. No reuse allowed without permission.

Volkow, N.D., Koob, G.F., and McLellan, A.T. 2016. "Neurobiologic Advances from the Brain Disease Model of Addiction." N Engl J Med 374(4): 363-71.

Volkow, N.D., Wang, G.-J., Fowler, J.S., Tomasi, D., Telang, F., and Baler, R. 2010. "Addiction: decreased reward sensitivity and increased expectation sensitivity conspire to overwhelm the brain's control circuit." BioEssays : news and reviews in molecular, cellular and developmental biology 32(9): 748-755.

Zhang, J.T., Yao, Y.W., Potenza, M.N., Xia, C.C., Lan, J., Liu, L., Wang, L.J., Liu, B., Ma, S.S., and Fang, X.Y. 2016. "Effects of craving behavioral intervention on neural substrates of cue-induced craving in Internet gaming disorder." Neuroimage Clin 12: 591-599.

Zhou, Y., Zhan, J., and Luo, J. 2017. "Predicting Multiple Risky Behaviors via Multimedia Content." 10540: 65-73. 
medRxiv preprint doi: https://doi.org/10.1101/2020.01.17.20017202; this version posted April 21, 2020. The copyright holder for this preprint (which was not certified by peer review) is the author/funder, who has granted medRxiv a license to display the preprint in perpetuity.

Supplementary file 1

Appendix

Stimuli presentation - the off-scanner paradigm

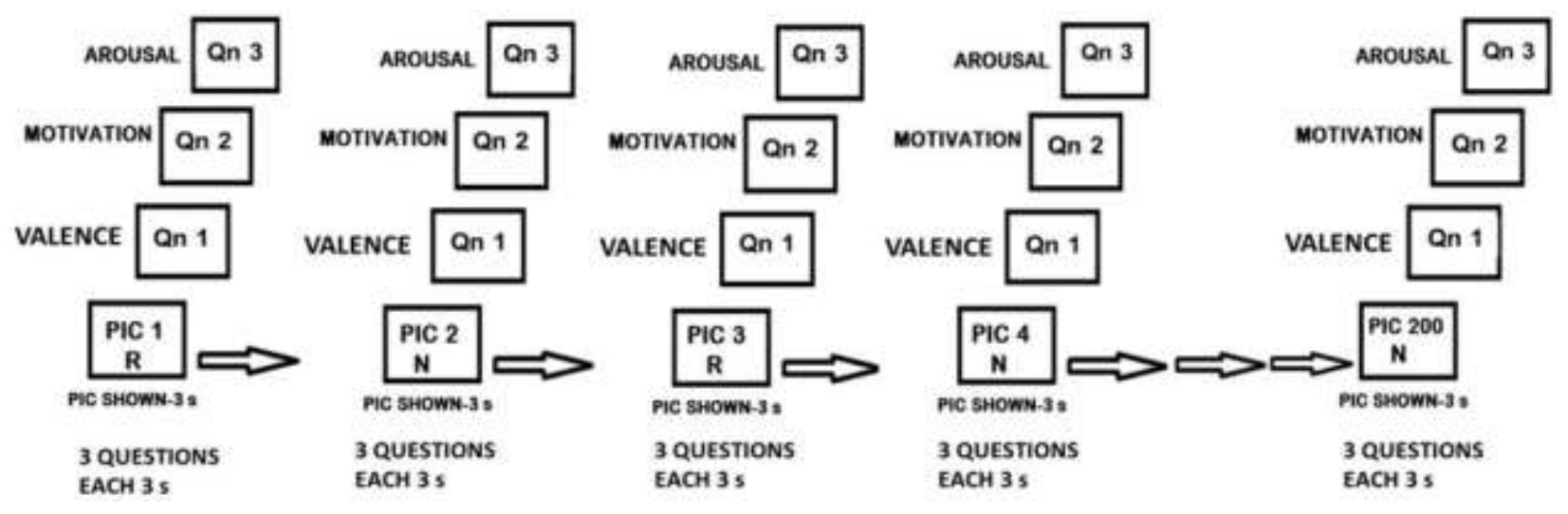

